\title{
Será que vai virar processo? Determinantes da elucidação dos homicídios dolosos em uma cidade brasileira $^{1}$
}

Ludmila Ribeiro ${ }^{2}$ (id

Flora Moara Lima ${ }^{3}$ (i)

Neste artigo analisamos dados de inquéritos policiais e processos penais de homicídios dolosos arquivados em Belo Horizonte entre os anos de 2003 e 2013, para entender os determinantes da elucidação desses homicídios. Como variáveis preditoras, usamos as características da vítima, os atributos do delito e a natureza dos procedimentos policiais. Os resultados informam que as características do assassinato e os métodos de descoberta da verdade (centrados no flagrante e na presença de testemunhas oculares do delito) são as variáveis que melhor explicam a diferença entre casos arquivados na polícia e na justiça. Todavia, o decurso do tempo tem papel de destaque, posto que inquéritos policiais não encerrados em até cinco anos têm chances irrisórias de serem transformados em processos penais.

Palavras-chave: elucidação; homicídios; Brasil; inquérito policial; sistema de justiça criminal

\section{Introdução ${ }^{4}$}

Em 14 de março de 2018, os jornais de todo o país noticiavam o assassinato de Marielle Franco, uma das vereadoras mais votadas na cidade do Rio de Janeiro em $2014^{5}$. Dois anos depois, quando encerramos a escrita deste artigo, a investigação policial apontou dois suspeitos, denunciados pelo Ministério Público para início do processo penal no Judiciário ${ }^{6}$, mas pouco avançara em termos de informações sobre as razões para esse

\footnotetext{
1 Trabalho realizado a partir do financiamento da Fapemig (APQ 00744-14).

2 Universidade Federal de Minas Gerais. Departamento de Sociologia, Belo Horizonte (MG), Brasil.

E-mail: <ludmila.ribeiro@gmail.com>.

3 Pontifícia Universidade Católica de Minas Gerais. Departamento de Ciências Sociais. Belo Horizonte (MG), Brasil. E-mail: <fmoara.lima@gmail.com>.

${ }^{4}$ As autoras agradecem aos pareceristas anônimos pelas sugestões que muito contribuíram para a versão final do texto, com pontuações que incluíram desde estratégias para melhorar a redação até uma outra modelagem para os dados.

5 Nesse sentido, ver: <https://g1.globo.com/rj/rio-de-janeiro/noticia/vereadora-do-psol-marielle-franco-emorta-a-tiros-no-centro-do-rio.ghtml>. Acesso em: 26 nov. 2018.

${ }^{6}$ Nesse sentido, ver: <https://g1.globo.com/rj/rio-de-janeiro/noticia/2019/03/12/policia-prende-suspeitospelos-assassinatos-da-vereadora-marielle-franco-e-anderson-gomes.ghtml>. Acesso em: 27 mar. 2019.
} 
assassinato $^{7}$. Infelizmente, esse padrão de investigação - em termos de tempo e dificuldade no apontamento de um suspeito - está longe de ser uma exceção quando falamos do fluxo do sistema de justiça criminal para os homicídios intencionais no Brasil ${ }^{8}$.

Em razão da ausência de um sistema de estatísticas criminais, concatenando as diversas etapas de processamento, como ocorre em outros países (Liem et al., 2018), as análises que procuram reconstituir o caminho percorrido pelos indivíduos e documentos no sistema de justiça criminal são muito artesanais (Oliveira e Machado, 2018). Os pesquisadores que se arriscam nesse empreendimento precisam coletar informações sobre o registro do crime pela Polícia Militar, a investigação pela Polícia Civil, a denúncia pelo Ministério Público, a defesa pela Defensoria Pública ou Privada, a decisão de pronúncia pelo juiz e a decisão final pelos Tribunais do Júri (Costa e Lima, 2018) ${ }^{9}$. Com o banco de dados em mãos, é possível compreender a influência das características dos envolvidos (como cor da pele, idade e sexo), das circunstâncias do delito (como local de ocorrência e arma utilizada) e dos métodos de descoberta da verdade (presença de testemunhas e prisão em flagrante) no tempo e desfecho das distintas etapas que compõem o fluxo de processamento (Vargas, 2014).

O homicídio intencional é um dos delitos com maior qualidade em termos de registro, posto que contabilizado pelas agências de saúde e segurança pública (Costa e Lima, 2018), além de ser um dos poucos crimes que aciona o Tribunal do Júri, o que significa um processamento mais longo e complexo (Oliveira e Machado, 2018). Por isso, tende a ser o crime preferencial para reconstituição dos padrões de seleção e filtragem que permeiam o fluxo do sistema de justiça criminal (Azevedo e Sinhoretto, 2018). A representação gráfica do fluxo é semelhante a um funil, com muitas mortes comunicadas à Polícia Civil, mas poucas transformadas em denúncia pelo Ministério Público, momento em que tem início o processo penal (Costa, 2015).

A ausência de dados integrados, que permitam o acompanhamento do homicídio desde o registro até o final do processo de responsabilização, faz com que, em comparação à produção internacional, quase nada saibamos sobre como as características do suspeito, os elementos do crime ou as formalidades da investigação aumentam ou diminuem as chances de início do processo judicial (Costa e Oliveira Júnior, 2016). Com vistas a suprir essa lacuna, o presente artigo tem o propósito de compreender os fatores que influenciam o desfecho da investigação policial ${ }^{10}$.

A proposta é fazer uma comparação pela semelhança. Inicialmente, identificamos

\footnotetext{
7 Nesse sentido, ver: <https://piaui.folha.uol.com.br/comeco-para-uma-historia-sem-fim/>. Acesso em: 8 nov. 2019.

8 Nesse sentido, ver: <https://www.hrw.org/world-report/2019/country-chapters/brazil>. Acesso em: 8 nov. 2019.

${ }^{9} \mathrm{O}$ processamento dos crimes dolosos contra a vida, consumados ou tentados (homicídio simples; homicídio qualificado; homicídio privilegiado; induzimento, instigação ou auxílio ao suicídio; infanticídio; aborto; feminicídio), é feito por meio de um procedimento processual bifásico, que sucede a investigação policial.

${ }_{10}$ Como marco conceitual, adotamos a definição de esclarecimento do homicídio doloso empregado pelo Instituto Sou da Paz (2017, p. 6), qual seja, oferecimento da denúncia no processo penal.
} 
nos estudos internacionais quais são as variáveis que explicam a elucidação policial. Depois, procuramos compreender se essas dimensões são capazes de ilustrar as diferenças entre os casos arquivados como inquéritos policiais e os arquivados como processos penais. Como contraponto empírico, será utilizada uma base de dados construída a partir da consulta a inquéritos policiais (casos não elucidados) e processos penais (casos elucidados) de homicídio doloso arquivados entre 2003 e 2013 na cidade de Belo Horizonte.

Para tanto, este artigo está organizado em cinco seções, além desta introdução e da conclusão, sendo que cada qual se orienta por uma pergunta específica. A primeira, denominada "O que podemos considerar como elucidação nos homicídios intencionais?", enumera as dificuldades encontradas na conceitualização e na compilação das taxas de esclarecimento de homicídios, tanto na literatura nacional como na internacional. A subsequente, intitulada "Os determinantes da elucidação de homicídios?", procura indicar, a partir da revisão da literatura internacional, como as características das vítimas, os atributos do delito e as nuances dos procedimentos policiais interferem no desfecho da investigação de mortes violentas.

A terceira seção é dedicada a descrever a metodologia empregada no estudo. Já a quarta, busca responder "Quais são as diferenças existentes entre inquéritos policiais e processos penais?", e, para tanto, são identificados os atributos que diferenciam os casos encerrados como inquéritos policiais daqueles arquivados como processos penais em Belo Horizonte entre 2003 e 2013. A quinta seção aplica modelos estatísticos para entendimento da realidade brasileira, o que permite responder à pergunta "Determinantes da elucidação: a literatura internacional explica a dinâmica de Belo Horizonte?". Nas considerações finais são enumeradas as lições aprendidas com essa análise.

\section{O que podemos considerar como elucidação nos homicídios intencionais?}

Os trabalhos sobre padrão de decisão no sistema de justiça criminal que têm como objeto de análise as mortes violentas intencionais destacam que o apontamento do responsável pelo delito é a fase mais problemática (Pastia, Davies e Wu, 2017). Em algumas localidades, vários são os corpos encontrados com marcas de violência e apenas uma parcela destes resultará na indicação de um suspeito (Carter e Carter, 2016), o que faz do trabalho policial uma fase crítica no fluxo do sistema de justiça (Hough, 2019). Se o caso "sobreviver" à fase de investigação policial, aumentam substantivamente as chances de ele resultar em punição pelo sistema de justiça (Jarvis, Mancik e Regoeczi, 2017).

De certa maneira, essa discussão também permeia o contexto brasileiro (Vargas, 2014). O estudo mais recente sobre o tema, realizado pelo Instituto Sou da Paz, constatou que "a investigação e processamento de homicídios por parte das instituições que compõem o sistema de justiça criminal e segurança no Brasil é ineficaz e ineficiente" (2017, p. 5). A elucidação do crime, que tem como objetivo apontar um suspeito que possa ser 
responsabilizado no âmbito do Poder Judiciário, é a fase na qual a maioria dos registros de homicídio intencional é encerrada (Misse, 2011; Costa, 2015; Costa e Lima, 2018). Apesar de a pergunta "quantos casos de assassinato são elucidados anualmente?" parecer relativamente simples, a resposta a ela é bastante complexa.

O primeiro ponto de controvérsia - entre a literatura nacional e a internacional diz respeito ao que pode ser considerado como elucidação. Nos Estados Unidos (Braga, Turchan e Barao, 2019) e na Europa (Liem et al., 2018), um assassinato é considerado elucidado quando há a prisão do suspeito, que passa a ser nomeado como o responsável pela morte e sujeito à acusação pública ou à negociação da culpa (como ocorre no plea bargain). Braga, Turchan e Barao (2019) destacam que existem outras formas de elucidação, as quais devem ser consideradas como excepcionais porque consistem no suicídio, no homicídio ou na morte do suspeito por causas naturais.

No Brasil, o apontamento de alguém como responsável pela morte de outrem não enseja a prisão ${ }^{11} \mathrm{e}$, em algumas situações, pode não resultar em processo penal. Várias investigações policiais são consideradas como malsucedidas em razão dos homicídios retaliatórios, que tendem a ceifar a vida dos suspeitos em razão dos conflitos de gangues e das dinâmicas de tráfico de drogas (Machado e Porto, 2016). Por isso, o Instituto Sou da Paz $(2017,2019)$ definiu a elucidação dos homicídios dolosos como aquelas situações em que as investigações resultam no apontamento de um suspeito $e$ na denúncia pelo Ministério Público. São excluídas da definição as situações excepcionais, em que o suspeito é identificado, mas o caso não resulta em desdobramentos policiais (indiciamento) e judiciais (denúncia) porque ele faleceu.

Seguindo essa definição, alguns pesquisadores calcularam a taxa de elucidação para o homicídio doloso. Esta varia entre 8\% (Rio de Janeiro) e 69\% (Brasília), como pode ser observado no Quadro 1:

\footnotetext{
${ }^{11}$ As razões para a prisão durante o processo são enumeradas no Código de Processo Penal, dividindo-se entre garantia da ordem pública, garantia da ordem econômica, conveniência da instrução criminal e da aplicação da lei penal. Assim, se um sujeito matou outrem, mas não se enquadra nessas quatro possibilidades de prisão provisória, ele irá responder ao processo em liberdade e não privado dela.
} 


\section{Quadro 1}

\section{Sumário das pesquisas que calcularam as taxas de elucidação de} homicídios dolosos

\begin{tabular}{|c|c|c|c|}
\hline Pesquisa & Abrangência & Período & $\begin{array}{c}\text { Taxa de } \\
\text { elucidação }\end{array}$ \\
\hline Soares (1996) & Rio de Janeiro & 1992 & $8 \%$ \\
\hline Rifiotis (2007) & Florianópolis & $2000-2006$ & $43 \%$ \\
\hline Ratton e Cireno (2007) & Recife & $2003-2005$ & $15 \%$ \\
\hline Misse e Vargas (2007) & Rio de Janeiro & $2000-2005$ & $14 \%$ \\
\hline Sapori (2007) & Belo Horizonte & $2000-2005$ & $15 \%$ \\
\hline Costa (2009) & Brasília & $2003-2007$ & $69 \%$ \\
\hline Ribeiro (2010) & São Paulo & $1991-1998$ & $22 \%$ \\
\hline Cano e Duarte (2010) & Rio de Janeiro & $2000-2007$ & $8 \%$ \\
\hline $\begin{array}{l}\text { Costa, Zackeski e } \\
\text { Maciel (2016) }\end{array}$ & Área metropolitana de Brasília & 2010 & $10 \%$ \\
\hline $\begin{array}{l}\text { Instituto Sou da Paz } \\
\text { (2017) }\end{array}$ & $\begin{array}{c}\text { Sete estados da federação } \\
\text { (Pará, Rio de Janeiro, Espírito } \\
\text { Santo, Rondônia, São Paulo e Mato } \\
\text { Grosso do Sul) }\end{array}$ & $\begin{array}{l}\text { Janeiro de } 2015 \\
\text { a junho de } 2017\end{array}$ & $21 \%$ \\
\hline $\begin{array}{l}\text { Instituto Sou da Paz } \\
\text { (2019) }\end{array}$ & $\begin{array}{c}\text { Doze estados da federação } \\
\text { (Acre, Amapá, Espírito Santo, Mato } \\
\text { Grosso, Mato Grosso do Sul, Pará, } \\
\text { Paraná, Piauí, Rio Grande do Sul, } \\
\text { Rondônia, Santa Catarina e São } \\
\text { Paulo) }\end{array}$ & $\begin{array}{c}\text { Janeiro de } 2015 \text { a } \\
\text { dezembro } 2016\end{array}$ & $27 \%$ \\
\hline
\end{tabular}

Fonte: Elaborado pelas autoras com base em dados da pesquisa.

O segundo ponto de controvérsia é o significado dos números listados no Quadro 1. Na Europa, os percentuais de elucidação de homicídios são sempre superiores a 80\%, alcançando $98 \%$ na Finlândia (Liem et al., 2018). Em outros locais, essas taxas variam entre 96\% (na Coreia do Sul), 91\% (na Nova Zelândia), 65\% (nos Estados Unidos da América) e 24\% (em Trinidad e Tobago) (UNODC, 2019). A taxa de elucidação na maioria das cidades brasileiras (para as quais temos informações válidas) é substancialmente menor que a de outros países, ainda que em nenhum país a polícia seja capaz de elucidar todos os assassinatos que chegam ao seu conhecimento (Petersen, 2017).

A terceira controvérsia diz respeito aos mecanismos causais que explicam a variação desses percentuais. Como destacam Braga, Turchan e Barao (2019, p. 2), apesar dos avanços na tecnologia forense e nos testes de DNA, as taxas de elucidação de homicídios nos Estados Unidos da América "diminuíram de 79\% em 1976 para 61\% em 2007 e permanecem abaixo de 67\% desde meados dos anos 2000". Entre os fatores apontados para tanto está "a crescente parcela de homicídios provenientes de atividades criminosas, como violência relacionada a gangues e drogas" (Braga, Turchan e Barao, 
2019, p. 10). Nessas situações, é difícil prender o suspeito após o delito e/ou conseguir informações sobre testemunhas oculares.

Se compararmos as taxas de elucidação de homicídios do Rio de Janeiro localidade representada como espaço que concentra muitas mortes violentas como resultado das disputas por mercados ilegais (Misse, 2010) - com lugares tradicionalmente vistos como seguros, como Santa Catarina (Rifiotis, 2006), poderíamos nos ver tentados a explicar os percentuais do Quadro 1 por meio dessa narrativa. Contudo, será mesmo que somente o tipo de violência interfere nas chances de elucidação?

Nos Estados Unidos da América, há uma ampla literatura sobre o esclarecimento dos homicídios dolosos, a qual tende a entender esse fenômeno como o resultado combinado de características das vítimas, dinâmica do delito e procedimentos adotados pela polícia para elucidação do caso (Regoeczi, Jarvis e Mancik, 2020). No Brasil, boa parte da literatura sobre o tema tende a explicar as taxas de elucidação recorrendo ao formato do sistema de justiça criminal, que mescla uma primeira etapa inquisitorial com outra acusatorial (Misse, 2011).

A fase policial, que se orienta por princípios inquisitoriais, busca descobrir a "verdade real" a partir da interrogação de suspeitos e testemunhas com vistas à formação de uma narrativa sobre o crime e o criminoso (Kant de Lima, 2004). Os problemas desse formato são o sigilo e a não admissão de contrariedade das narrativas desenvolvidas pela polícia (Kant de Lima, 1997). Em razão dessa mesma tradição, provas periciais (como exames de balística ou DNA) tendem a ter pouco espaço na investigação (Costa e Oliveira Júnior, 2016), que termina por privilegiar o depoimento das testemunhas oculares (Platero e Vargas, 2017). O problema dessa opção é que as falas transcritas indiretamente podem ser reinterpretadas para forjar uma narrativa policial mais convincente (Santos, 2018), garantindo o desfecho desejado, qual seja, início ou não do processo penal (Kant de Lima e Mouzinho, 2017).

O modelo inquisitorial, ao privilegiar o segredo e dar fé pública ao que o policial escreve como relato do que as testemunhas disseram (Kant de Lima, 2004) ${ }^{12}$, permite à polícia recorrer ao criminoso para entender sobre o crime e não o inverso (Paixão, 1982). Com isso, a elucidação passa a ser vista como função do tirocínio policial (Mingardi, 1992), uma lógica em uso compartilhada por todos os policiais sobre quais são as características que transformam um sujeito qualquer em suspeito, ainda que não existam evidências de sua participação no cometimento do crime (Paixão, 1982; Mingardi, 1992; Misse, 2011) ${ }^{13}$.

\footnotetext{
12 Isso ocorre porque não há transcrição direta do depoimento das testemunhas, mas somente indireta. Assim, nos documentos policiais temos a sumarização do que o policial alega ter a pessoa dito e do que, na perspectiva dele, a testemunha Ihe respondeu. Para maiores detalhes sobre como o inquérito policial funciona no Brasil, ver Misse (2011).

13 Santos (2018, p. 47), ao descrever essa realidade em Portugal, destaca que o modelo inquisitorial favorece a utilização "de um 'impulso central', um ponto de partida, que conduz os investigadores criminais no processo de 'reconstrução' da sequência de eventos de cada crime, recorrendo para tal à interpretação de sinais de atividade e movimento na cena de crime, à aplicação de reportórios de conhecimento acerca de comportamentos criminais tipificados, bem como ao conhecimento geral acerca de cada tipo de crime". Acreditamos que essa lógica em curso também se aplica à forma de realização do inquérito policial e, por
} 
Se a polícia não tem um suspeito horas após o assassinato, alguém que seja visto naquela área como possível criminoso, dificilmente essa morte resultará num processo penal (Costa, 2015; Costa e Oliveira Júnior, 2016).

Os efeitos dessa marca de origem são enormes porque o processo penal, que é obrigatório no caso brasileiro, só pode se iniciar se o promotor demonstrar indícios de autoria e materialidade do delito (Kant de Lima e Mouzinho, 2017). Como o promotor não participa ativamente das investigações realizadas pela polícia (Paes, 2013), a única alternativa é apresentar ao juiz uma denúncia que terá como base o relatório final do delegado de polícia (Vargas e Rodrigues, 2011). Legitimam-se, assim, as práticas inquisitoriais porque são elas que vão permitir a transformação do suspeito em acusado (Santos, 2018), viabilizando o início do processo penal (Kant de Lima, 2004).

Portanto, os percentuais apresentados no Quadro 1 revelam que somente uma pequena parcela dos homicídios dolosos registrados pela polícia se transformou em processo penal. São esses os casos em que os policiais conseguiram indicar um suspeito, que estava vivo no momento de encerramento do inquérito policial, razão pela qual os números do Quadro 1 são muito ilustrativos da incapacidade das polícias investigativas de cumprir suas missões institucionais (Costa, 2009). Todavia, esses números nada nos dizem sobre quais elementos contribuem para que o homicídio doloso seja elucidado (Costa e Lima, 2018). Ou seja, mais do que reconstituir e descrever o fluxo de processamento, destacando as suas características inquisitoriais, é preciso entender os determinantes do "sucesso" na elucidação do homicídio, o que explicaria a variação das taxas (Oliveira e Machado, 2018). Pesquisas desse tipo ainda são raras no Brasil (Costa, 2015), mas bastante frequentes nos Estados Unidos da América (Keel, Jarvis e Muirhead, 2009), razão pela qual tomaremos essa literatura como ponto de partida da nossa análise.

\section{Os determinantes da elucidação de homicídios}

Na literatura internacional, três são os fatores que contribuem para a elucidação do homicídio: características das vítimas (sexo, idade e raça), atributos do delito (local de ocorrência do crime, arma utilizada, horário do assassinato e associação com atividades criminais) e procedimentos policiais (presença de testemunhas oculares, perícias e prisão em flagrante) (Regoeczi, Jarvis e Mancik, 2020).

\section{Características das vítimas}

Algumas pesquisas da sociologia do direito têm observado que existe uma enorme variação na quantidade de leis aplicadas de acordo com a geometria social dos envolvidos em um conflito (Black, 1976). Essa categoria é definida pelas características dos autores e

conseguinte, de construção do processo penal no Brasil. 
das vítimas do delito, das relações que elas estabelecem entre si e do contexto social mais amplo em que elas interagem (Jarvis, Mancik e Regoeczi, 2017).

Donald Black (1976) sublinha que as vítimas de menor status são as que tendem a receber menor quantidade de lei, posto que as organizações policiais e judiciais tratariam os crimes que ocorrem contra elas como de menor importância. Assim, homicídios com vítimas femininas, jovens e de minorias étnicas teriam menos chances de esclarecimento do que aqueles com vítimas masculinas, idosas e brancas (Black, 1976, p. 21). Ou seja, é de esperar que homicídios de "vítimas desvalorizadas" tenham menores chances de elucidação. Como esses indivíduos possuem menor valor para a sociedade, as polícias dificilmente se empenhariam em elucidar tais delitos, deixando-os sem punição.

Desde a formulação da teoria da vítima desvalorizada, vários são os estudos que procuram verificar como esta se faz ou não presente na realidade norte-americana (Hough, 2019) e de que maneira pode ser utilizada para explicar as taxas de elucidação em outros países (Liem et al., 2018). Ao analisar o caso do Canadá, Pastia, Davies e Wu (2017) constataram que homicídios domésticos que vitimam mulheres pobres e negras são os que têm maiores chances de elucidação porque contam com grande número de testemunhas dispostas a colaborar com a polícia. No entender dos autores, trata-se de uma negação da teoria de Black (1976), indicando como o tipo de delito seria um elemento mais importante para a compreensão dos padrões de elucidação do que as características da vítima.

Nos Estados Unidos da América, a raça da vítima é uma variável que ora se comporta na direção da teoria de Black (1976), ora na direção verificada por Pastia, Davies e Wu (2017). Algumas análises sublinham que assassinatos de negros têm menores chances de elucidação, já que as polícias tenderiam a acreditar que esses casos serão resolvidos de outra maneira (como a retaliação), razão pela qual seria "perda de tempo" concentrar esforços neles (Keel, Jarvis e Muirhead, 2009). Outras salientam que tudo depende da forma como a raça é mensurada e, por isso, categorias binárias (brancos e não brancos) poderiam escamotear uma série de discriminações, o que resultaria na não significância dessa variável em modelos estatísticos (Banziger e Killias, 2014; Roberts e Lyons, 2011).

Na Europa, Liem et al. (2018) constataram que o gênero (ser mulher), a idade (ser muito jovem ou muito velho) e a raça (pertencer a uma minoria étnica) são elementos determinantes para elucidação de homicídios na Suécia e na Holanda, mas têm pouco impacto nos outros países que compõem a base de dados do Homicide Monitor. Ou seja, o contexto de pesquisa faz com que o papel desempenhado pelas características das vítimas nas chances de elucidação do homicídio pela polícia seja diferenciado (Riedel, 2008).

Os indivíduos mais propensos a serem mortos sem que isso signifique elevada comoção em nossa sociedade e resposta do sistema de justiça criminal são os homens jovens, negros e residentes de periferia (Vargas, 2014). São estes também os mais 
suscetíveis à violência policial ${ }^{14}$, o que se convencionou chamar de genocídio da população jovem e negra (Sinhoretto et al., 2014). Nesses casos, "o raciocínio social implícito de que certas vidas - as negras em especial - não importam perpetua as atitudes e crenças da sociedade em geral que não se mobiliza para enfrentar a desigualdade social também no esclarecimento das mortes por homicídios" (Platero e Vargas, 2017, p. 637).

Portanto, a perspectiva da "vítima desvalorizada" (Black, 1976) poderia ser traduzida no Brasil pela categoria "bandido", que identifica o sujeito legitimamente matável (Misse, 2010). Assim, é de esperar que as mortes de sujeitos do sexo masculino, jovens e negros sejam as mais propensas a ter o inquérito policial arquivado sem elucidação.

\section{Atributos do delito}

Outro elemento destacado nos estudos internacionais como variável que influencia as chances de elucidação é a discricionariedade que o policial possui para iniciar os procedimentos investigatórios. Jarvis, Mancik e Regoeczi (2017, p. 8) enfatizam que "prioridades políticas e diretrizes de gestão podem impactar as probabilidades de resolução de casos", o que significa dizer que a priorização de crimes para investigação ou mesmo os métodos que, na perspectiva do policial, devem ou não ser acionados pela polícia podem influenciar no desfecho dessa etapa.

A escolha de qual assassinato deve ser investigado prioritariamente é, inicialmente, informada pelo perfil da vítima (por exemplo, se é ou não um "bandido"), mas as características situacionais do delito também têm papel de destaque. A chamada para a polícia pode apenas informar que há um corpo, sem dar maiores características deste, situação em que a área de ocorrência do delito será um definidor da disposição dos policiais em responder a esse incidente (Petersen, 2017). Nos bairros de população negra, por exemplo, a investigação policial tende a ser menos eficiente porque a polícia demora a chegar, fazendo com que a quantidade de casos elucidados seja substantivamente menor em comparação a áreas afluentes da cidade (Carter e Carter, 2016). Novamente, estamos diante de características socioeconômicas, o que reproduziria a teoria de Black (1976) sobre a quantidade de lei destinada a cada grupo social.

Para escapar dessa tautologia, Banziger e Killias (2014) sugerem que, em vez do bairro, outros elementos circunstanciais sejam considerados. Para eles, a polícia tende a preferir casos de fácil resolução, como os delitos de proximidade, que ocorrem na

\footnotetext{
14 Em paralelo à elaboração deste artigo, está em discussão no país um projeto de lei, proposto em fevereiro de 2019 pelo ministro da Justiça, denominado "Projeto de lei anticrime". Nesse sentido ver: <https://www.justica.gov.br/news/collective-nitf-content-1549284631.06/projeto-de-lei-anticrime.pdf>. Acesso em: 1 ago. 2019. Um dos pontos mais polêmicos do projeto se refere ao excludente de ilicitude, que já é assegurado no Código Penal Brasileiro; entretanto, há um debate, proposto pelo projeto, sobre a necessidade de alterar a lei para que agentes públicos na função de policiamento tenham maiores garantias. Até o fechamento deste artigo, em dezembro de 2019, não havia uma definição sobre o assunto. Contudo, há certo consenso entre especialistas sobre quão problemático é o tema para a potencialização do genocídio da população jovem e negra.
} 
residência do algoz, a partir do uso de facas ou estrangulamento, quando muitas testemunhas podem ouvir os gritos da vítima. Nessas situações, os próprios elementos do delito fazem com que a investigação seja breve e seus resultados sejam muito palpáveis, o que aumentaria o reconhecimento da qualidade do serviço prestado pela polícia à população (Regoeczi, Jarvis e Mancik, 2020).

Nessa mesma direção, Liem et al. (2018) propõem a incorporação de elementos como o lugar do delito, o momento de sua ocorrência e o instrumento utilizado pelo perpetrador como variáveis que ajudariam a compreender os padrões de elucidação. Ao testar essa hipótese, os autores constataram que casos de violência doméstica, em que facas e as próprias mãos são usadas para causar a morte de outrem, são mais facilmente elucidados do que homicídios relacionados a outros delitos, como o tráfico de drogas e as brigas entre gangues. Estes têm na arma de fogo o seu principal meio de execução e contam com a vantagem de serem perpetrados nas madrugadas, em ruas desertas, nas quais dificilmente alguém verá o que ocorreu, o que dificulta a elucidação (Keel, Jarvis e Muirhead, 2009).

Ao realizarem um exercício semelhante, mas levando em consideração as motivações que os policiais atribuíam às mortes violentas, Roberts e Lyons (2011) constataram que os homicídios relacionados a disputas entre gangues ou tráfico de drogas têm menores chances de elucidação. Muitas vezes, a própria codificação do caso como relacionado a esses grupos é indicativo de que dificilmente ele será elucidado (Braga, Turchan e Barao, 2019). Nesse sentido, a diferenciação entre as violências de proximidade e as relativas ao criminal milieu seria a melhor preditora do resultado do trabalho policial (Riedel, 2008).

No Brasil, as características do delito são comumente utilizadas como explicações para a baixa taxa de elucidação de homicídios nas pesquisas que se utilizam das representações sociais dos operadores de segurança pública e justiça criminal (Machado e Porto, 2016). Para os policiais, a disputa entre gangues tornaria muito difícil a coleta de informações junto à população, que, por temer represálias, não colabora com a polícia (Costa, Zackeski e Maciel, 2016). Sem testemunhas, fica difícil estabelecer uma linha de raciocínio sobre o crime e como ele aconteceu, o que dificulta o esclarecimento (Costa, 2009). Como a maioria das mortes violentas, letais e intencionais ocorre nas áreas periféricas das grandes cidades, nas quais a polícia tem enorme dificuldade em se fazer presente, poucos seriam os casos elucidados (Costa, 2015).

\section{Procedimentos mobilizados na investigação policial}

Nos seriados norte-americanos, as mortes violentas intencionais são esclarecidas com a interdição da área em que o assassinato ocorreu, coleta de vestígios de DNA do agressor no corpo da vítima, exame de balística e oitiva da testemunha ocular do crime, 
descoberta em razão dos bons relacionamentos de alguns policiais com pessoas que residem na comunidade onde o delito ocorreu ${ }^{15}$.

Para que a fiç̧ão possa acompanhar a realidade, a investigação deve ser iniciada tão logo o crime seja comunicado à polícia (Regoeczi, Jarvis e Mancik, 2008). Caso isso não aconteça, pode ter início a destruição de provas ou, até mesmo, a ocorrência do homicídio retaliatório que irá ceifar a vida do agressor (Keel, Jarvis e Muirhead, 2009). Carter e Carter (2016, p. 154) chamam atenção para o fato de que "o homicídio é o tipo de crime com maior probabilidade de ser influenciado pelos recursos disponíveis para investigar", uma vez que a quantidade de policiais prontos para se deslocar aos chamados influencia no tempo de resposta e, por conseguinte, na quantidade de evidências e testemunhos coletados. Tais estudos sublinham que crimes não elucidados em até 48 horas dificilmente sobreviverão à fase policial (Riedel, 2008).

Nesse contexto, o horário de ocorrência do crime ganha relevo. "As ofensas ocorridas na madrugada ou nas primeiras horas da manhã podem resultar em atrasos na entrevista de testemunhas e na coleta e processamento de evidências físicas relativas às ofensas ocorridas durante o dia" (Jarvis, Mancik e Regoeczi, 2017, p. 17). Geralmente, esse é o momento de troca de turnos das equipes ou quando as delegacias de polícia estão funcionando no sistema de plantão, com poucos policiais, o que dificulta os deslocamentos para identificação dos vestígios do crime (Braga, Turchan e Barao, 2019).

Qualquer que seja o horário de ocorrência do delito, quando a polícia chega até o corpo, a primeira providência deveria ser a coleta de vestígios físicos, com destaque para as impressões digitais e restos de DNA sobre o corpo da vítima (Schroeder e White, 2009). Ato contínuo está o registro de todos os presentes no local do delito, posto que crimes com muitas testemunhas têm mais chances de elucidação (Carter e Carter, 2016).

Nos dias subsequentes ao assassinato, a polícia deve retornar ao bairro para conversar com outros indivíduos que não estavam no local do crime, mas podem ter ouvido ou visto algo, conhecer autores e vítimas (Jarvis, Mancik e Regoeczi, 2017). Nesse ponto, a confiança que a população deposita na polícia é o elemento-chave para que as testemunhas possam fornecer aos investigadores informações sobre os potenciais infratores (Braga e Dusseault, 2018). Algumas podem preferir o silêncio por medo de retaliação, o que seria típico das áreas que concentram grande número de homicídios (Braga, Turchan e Barao, 2019). Outras podem optar pela colaboração mais imediata com a polícia por temer que novas mortes possam acontecer na localidade (Schroeder e White, 2009).

Se todos os procedimentos listados (coleta de vestígios, entrevista de testemunhas e conversas com residentes na área do crime) são realizados prontamente, aumenta-se a chance de elucidação do homicídio intencional (Riedel, 2008), o que cria um círculo virtuoso entre a polícia e a comunidade (Santos, 2018). Braga e Dusseault (2018) chegam a afirmar

\footnotetext{
15 Um exemplo seria o seriado CSI (Crime, scene, investigation), cujas informações podem ser acessadas
} em: <https://www.minhaserie.com.br/serie/26-csi>. Acesso em: 27 mar. 2019. 
que, quanto maior a capacidade da polícia para esclarecer as mortes violentas no menor lapso temporal, maior a disposição dos indivíduos em cooperar com ela. É por essa razão que a presença de testemunhas do delito pode ser lida como uma proxy de legitimidade policial (Regoeczi, Jarvis e Mancik, 2008).

No Brasil, a organização do trabalho policial é diversa da observada nos seriados e nos estudos acadêmicos norte-americanos. Inicialmente, são duas as polícias responsáveis pelas atividades de policiamento: enquanto o patrulhamento ostensivo cabe à Polícia Militar $(P M)$, a investigação penal compete à Polícia Civil (PC). Em razão das disputas corporativas entre as instituições, não raro, quando a PC é avisada da existência do cadáver, as provas mais imediatas já foram destruídas e as testemunhas não se encontram nas imediações do crime (Platero e Vargas, 2017).

Quando a Polícia Civil começa a realizar o seu trabalho, a tradição inquisitorial passa a orientar a descoberta do que aconteceu (Kant de Lima, 2004). Se nos Estados Unidos da América a investigação é realizada para que um suspeito possa ser preso, no Brasil, a polícia inverte essa lógica (Paixão, 1982). Muitas vezes, o trabalho policial é iniciado com a prisão de algum suspeito porque ele estava nas imediações do delito, o que configuraria o flagrante (Costa e Oliveira Júnior, 2016). Essas são as situações preferenciais por parte das polícias, porque o flagrante dispensa a investigação que deveria ser realizada no âmbito do inquérito policial (Misse, 2011), fazendo com que o caso possa ser rapidamente encaminhado ao Ministério Público para denúncia e início do processo policial (Ratton e Cireno, 2007).

No modelo inquisitorial, as testemunhas são preferidas às perícias, dada a maior facilidade de coleta e tradução de falas para a linguagem do inquérito em comparação com a realização de procedimentos mais técnicos (Misse, 2011; Santos, 2018). Em vez de a polícia centrar os seus esforços em identificar testemunhas do fato, boa parte da investigação é destinada a ouvir as testemunhas de caráter, que irão dizer sobre a personalidade dos envolvidos (Costa, Zackeski e Maciel, 2016). Soma-se a isso a baixa confiança na polícia em áreas periféricas que concentram muitos homicídios (Costa, 2015), o que diminui sensivelmente a disposição dos moradores em colaborar, sobretudo, em casos relacionados ao tráfico de drogas (Machado e Porto, 2016). Resta aos policiais procurar potenciais suspeitos para, a partir de sua detenção, verificar se há alguma correspondência entre estes e os homicídios que foram registrados nas delegacias de polícia (Paixão, 1982; Mingardi, 1992) ${ }^{16}$.

\footnotetext{
16 Um bom resumo de como o modelo inquisitorial interfere diretamente nas práticas que serão acionadas pela Polícia Civil é apresentado por Kant de Lima e Mouzinho (2017, p. 519), os quais descrevem tais procedimentos da seguinte maneira: "O inquérito policial é um procedimento administrativo, não judicial, e por isso mesmo pode ter caráter explicitamente inquisitorial, isto é, registrar por escrito, com fé pública, emprestada pelo cartório que a delegacia possui, informações obtidas dos envolvidos sem que estes tenham conhecimento das suspeitas contra eles. Os registros policiais, assim, constituem-se em afirmações fidedignas que reforçam a presunção de culpa dos envolvidos, seguindo entranhados no processo com a indicação dos elementos que formaram a convicção da Polícia sobre sua culpabilidade. Esses registros, na forma de autos de um Inquérito, são encaminhados ao Ministério Público, que faz a Denúncia e a encaminha
} 
Vargas e Rodrigues (2011) sinalizam que o flagrante registrado no inquérito policial articula o sistema de justiça criminal, permitindo a concatenação entre as diversas agências encarregadas de apontar e processar um suspeito pela prática de um assassinato. Dessa maneira, o flagrante seria o elemento mais importante - se não o primordial - para a transformação do registro policial em processo penal.

Portanto, de acordo com a revisão de literatura internacional, os percentuais de esclarecimento de homicídios dolosos são muito aquém dos esperados. A nossa hipótese é de que essa taxa resulta da combinação de vítimas desvalorizadas, homicídios associados ao criminal milieu e procedimentos policiais eminentemente inquisitoriais, pouco lastreados em provas técnicas e muito concatenados à prisão em flagrante. Ou seja, a combinação entre características das vítimas, atributos do crime e mecanismos de descoberta da verdade é o que explica a pequena chance de esclarecimento de homicídios dolosos no Brasil. Vejamos se essa hipótese encontra ressonância nos dados coletados em Belo Horizonte.

\section{Metodologia}

O objetivo do presente artigo é entender se as variáveis que explicam a elucidação dos homicídios intencionais na literatura internacional podem ser utilizadas para a compreensão da diferença entre os casos que foram arquivados como inquéritos policiais e os arquivados como processos penais em Belo Horizonte entre os anos de 2003 e 2013.

Em solo brasileiro, não contamos com um sistema de informações que nos permita conhecer prontamente o desfecho da investigação policial dos homicídios intencionais (Costa e Lima, 2018). Para suprimir essa lacuna, os estudos se utilizam de três metodologias de coleta de dados: transversal, que consiste no contraste dos números totais registrados em cada organização, de forma a comparar as distintas produções decisórias (Cano e Duarte, 2010); longitudinal prospectiva, na qual o pesquisador acompanha a construção do processo de incriminação, desde o registro do crime na polícia até a sentença no Judiciário (Misse e Vargas, 2007); e longitudinal retrospectiva, a qual parte de todos os casos encerrados em dado momento do tempo para reconstituir o fluxo até o registro da ocorrência (Oliveira e Machado, 2018).

A metodologia transversal é a menos acurada, pois considera as estatísticas totais obtidas nas diferentes organizações (Polícia Militar, Polícia Civil, Ministério Público e Judiciário) como se elas correspondessem aos mesmos crimes e mesmos momentos, o que não é necessariamente real (Misse e Vargas, 2007). O maior problema desse desenho é o não acompanhamento do percurso de incriminação, sendo a maior vantagem a comparação de registros nas distintas etapas do fluxo de processamento (Cano e Duarte,

ao juiz, que a aceita, ou não. Somente após esse procedimento é que o processo se torna efetivamente público e os envolvidos tomam conhecimento das acusações". 
2010). É a partir dessa metodologia que o Instituto Sou da Paz $(2017,2019)$ constrói a cada dois anos o mapa da impunidade no Brasil.

A metodologia longitudinal prospectiva é a mais acurada, pois permite a sistematização em detalhe dos casos que se encerram ao longo do fluxo, com avaliações de cunho qualitativo sobre como o processo decisório foi construído (Oliveira e Machado, 2018). Porém, é a mais difícil de ser operacionalizada, pois não se sabe ao certo quanto tempo demorará para que as ocorrências inicialmente registradas na polícia sejam processadas pela justiça (Vargas, 2014). Atualmente, o monitor da violência acompanha 1.195 homicídios registrados em todo o país entre 21 e 27 de agosto de $2017^{17}$. Dois anos depois do início do monitoramento, $52 \%$ das mortes tinham sido esclarecidas, mas menos de $5 \%$ tinham recebido uma decisão final no Judiciário.

A metodologia longitudinal retrospectiva tem a vantagem de utilizar todos os procedimentos encerrados na polícia e na justiça com o emprego de amostras e questionários estruturados (Cano e Duarte, 2010). Mas tem a desvantagem de se referir a crimes que ocorreram em momentos distintos, ainda que tenham recebido a decisão final no mesmo ano (Oliveira e Machado, 2018).

Neste estudo, utilizamos a metodologia longitudinal retrospectiva. Consideramos como universo todos os documentos relativos aos homicídios dolosos arquivados em Belo Horizonte, o que permitiu tanto a análise dos casos elucidados (encerrados como processos penais) como não elucidados (encerrados como inquéritos policiais). O ponto de partida foi o arquivamento, porque cabe ao Poder Judiciário a guarda de toda a documentação (da polícia e da justiça), já que o nosso Código de Processo Penal (CPP) obriga o Judiciário a se pronunciar sobre o momento em que os inquéritos policiais sem autoria devem ser encerrados ${ }^{18}$, não sendo de competência da autoridade policial decidir sobre o fim dessa investigação ${ }^{19}$. Esse mesmo arquivo guarda todos processos penais encerrados com ou sem sentença final.

Uma vez estabelecida a metodologia que orientaria a pesquisa, o segundo passo foi a delimitação do recorte temporal. Em Belo Horizonte, entre os anos de 2003 e 2013, os homicídios dolosos viveram um período de ascensão e queda, em razão de diversas políticas públicas implementadas na cidade com vistas a prevenir esses incidentes e a garantir uma resposta mais efetiva a esses episódios (Sapori, 2007). Essa é também uma década especial em termos de funcionamento do sistema de justiça criminal, já que as agências estavam simultaneamente engajadas numa melhor articulação para processar

\footnotetext{
17 Nesse sentido, ver: <https://g1.globo.com/monitor-da-violencia/noticia/2019/09/22/monitor-daviolencia-dois-anos-depois-quase-metade-dos-casos-de-morte-violenta-continua-em-aberto-napolicia.ghtml>. Acesso em: 9 mar. 2020.

$18 \mathrm{CPP}$, Art. 18. Depois de ordenado o arquivamento do inquérito pela autoridade judiciária, por falta de base para a denúncia, a autoridade policial poderá proceder a novas pesquisas, se de outras provas tiver notícia.

${ }^{19} \mathrm{CPP}$, Art. 17. A autoridade policial não poderá mandar arquivar autos de inquérito.
} 
aqueles delitos que contavam com um conjunto probatório mínimo em decorrência da Estratégia Nacional de Justiça e Segurança Pública (Enasp).

A Enasp visava promover a articulação dos órgãos responsáveis pela segurança pública, a partir da coordenação das ações de combate à violência e de políticas nacionais sobre o tema (Ferraz, 2019) ${ }^{20}$. Suas metas foram estabelecidas em 2010, 2011 e 2012. Inicialmente, elas determinavam a conclusão de todos os inquéritos e procedimentos que investigavam os homicídios dolosos instaurados até o ano de 2007, sendo que, ao longo dos anos subsequentes, as metas tiveram o ano de instauração dos inquéritos adaptado sucessivamente para 2008 e 2009. Ao determinar o encerramento de investigações que se mostravam infrutíferas de maneira imediata, a Enasp contribuiu para que os procedimentos que se protelavam nas delegacias, por meio de infinitas solicitações de dilações de prazo, fossem encerrados pelo Judiciário ${ }^{21}$. Logo, o recorte estabelecido pela pesquisa cobriu uma década (2003-2013) porque permitiria a análise do padrão do fluxo de processamento antes e depois do estabelecimento das metas da Enasp.

Entre os anos de 2003 e 2013, foram arquivados nos Tribunais do Júri de Belo Horizonte uma miríade de documentos relacionados aos homicídios dolosos tentados e consumados ocorridos na capital em anos diversos. Nessa década, o arquivo do Júri recebeu 5.112 inquéritos policiais e 4.221 processos penais ${ }^{22}$.

Para cobrir esse universo, foi criada uma amostra que levava em consideração a natureza do procedimento (inquérito policial ou processo penal) e o ano em que o arquivamento ocorreu. Em seguida, os casos foram sorteados aleatoriamente até o montante estabelecido como mínimo para a geração de uma amostra confiável sobre toda a população de documentos. O terceiro passo foi a consulta e análise desse material a partir de questionário estruturado formatado para a finalidade de reconstituição do fluxo de processamento. Ao final foi gerada uma base de dados com 823 casos, com margem de erro total de 3,3 pontos percentuais e nível de confiança de 95\% (Tabela 1):

\footnotetext{
20 Sobre o assunto, ver: <http://www.cnj.jus.br/programas-e-acoes/metas-enasp>. Acesso em: 1 ago. 2019.

21 Houve um aumento absoluto dos arquivamentos, tanto de inquéritos como de processos, sendo que proporcionalmente há mais inquéritos encerrados sem elucidação do que processos encerrados por quaisquer motivos.

${ }^{22}$ A desagregação da quantidade de casos arquivados por ano, de acordo com a natureza do procedimento, indica que, a partir do momento em que a Enasp entra em operação, há aumento considerável do arquivamento de inquéritos policiais e redução de processos penais.
} 
Tabela 1

Quantidade de casos no universo e na amostra - Processos penais e inquéritos policiais de homicídio doloso (tentados e consumados), arquivados em Belo Horizonte entre 2003 e 2013

\begin{tabular}{|l|c|c|c|}
\hline \multirow{2}{*}{ Universo } & Inquéritos Policiais & Processos Penais & Total \\
\cline { 2 - 4 } & 5.112 & 4.221 & 9.333 \\
\hline \multirow{2}{*}{ Amostra } & $55 \%$ & $45 \%$ & $100 \%$ \\
\cline { 2 - 4 } & 431 & 392 & 823 \\
\hline
\end{tabular}

Fonte: Elaborada pelas autoras com base nos dados da pesquisa.

Com a base de dados em mãos, a tarefa seguinte foi reconstruir o fluxo de processamento, tomando como base o desenho transversal, ou seja, aquele que permite contrastar a quantidade de homicídios dolosos tentados e consumados registrados na polícia, com os inquéritos policiais e processos penais existentes nesse período (Cano e Duarte, 2010). A partir dos números reunidos, estimamos que $20 \%$ dos homicídios dolosos (tentados ou consumados) acontecidos em Belo Horizonte se transformaram em processos penais ao longo da década (2003-2013).

A taxa de elucidação guarda proximidade com o percentual encontrado por Sapori (2007) para os homicídios dolosos consumados em Belo Horizonte no começo da década passada - 15\% (Quadro 1). Trata-se de número muito semelhante à média nacional calculada pelo Sou da Paz por meio dessa mesma metodologia, o que faria de Belo Horizonte um arquétipo em termos de represamento do fluxo de processamento dos homicídios dolosos (tentados e consumados) na fase policial (Tabela 2):

\section{Tabela 2}

Número de ocorrências, processos e sentenças por homicídios dolosos tentados e consumados - calculados a partir da metodologia transversal Belo Horizonte (2003-2013)

\begin{tabular}{|l|c|c|}
\hline Categoria & Número absoluto & Percentual \\
\hline Ocorrências & 21.534 & 100 \\
\hline Processos & 4.221 & 20 \\
\hline Sentenças & 1.760 & 8 \\
\hline Condenações & 1.270 & 6 \\
\hline
\end{tabular}

Fonte: Ocorrências: Índice Mineiro de Responsabilidade Social (<http://imrs.fjp.mg.gov.br/>). Processos: Tribunal de Justiça de Minas Gerais. Sentenças: Ribeiro, Lima e Maia (2017).

Superar o gargalo da fase policial não é sinônimo de sucesso na fase judicial, posto que a passagem de uma etapa a outra é caracterizada pela perda progressiva de ocorrências (Vargas, 2014). Em Belo Horizonte, entre 2003 e 2013, estimamos que 8\% dos homicídios dolosos (tentados e consumados) registrados chegaram à sentença do júri, sendo que $6 \%$ foram encerrados com uma sentença de condenação. Esse percentual é semelhante ao observado por Ribeiro (2010) para o estado de São Paulo entre os anos de 1991 e 1998, o que pode ser mais um indicativo de que a capital mineira é um exemplo do que ocorre em outras regiões do país. 
Neste artigo, optamos por entender os determinantes da elucidação dos homicídios dolosos consumados e excluímos da base de dados construída na pesquisa as tentativas de homicídio. Nessas situações, como a vítima está viva, ela pode auxiliar a polícia no apontamento do suspeito, o que faz com que a dinâmica de investigações seja substancialmente distinta daqueles casos em que ela faleceu (Braga e Dusseault, 2018). Analisamos 613 casos (352 inquéritos policiais e 261 processos penais), sendo esse o total que será utilizado nas análises subsequentes (Tabela 3) ${ }^{23}$ :

Tabela 3

\section{Distribuição dos homicídios dolosos consumados nos inquéritos policiais (casos não elucidados) e nos processos penais (casos elucidados) Belo Horizonte (2003-2013)}

\begin{tabular}{|l|c|c|}
\hline Tipo de procedimento & Frequência & Porcentagem \\
\hline Inquérito Policial & 352 & 57,4 \\
\hline Processo de Homicídio & 261 & 42,6 \\
\hline Total & 613 & 100 \\
\hline
\end{tabular}

Fonte: Elaborada pelas autoras com base nos dados da pesquisa.

A nossa variável dependente é, portanto, a elucidação. Ela recebeu valor 0 para os casos não elucidados, ou seja, aqueles encerrados como inquéritos policiais porque o Ministério Público não ofereceu a denúncia para início do processo penal. E recebeu valor 1 para os casos elucidados, aqueles encerrados como processos penais, porque os supostos autores dos delitos foram publicamente acusados, momento a partir do qual se inicia o processo penal.

Para entender a diferença entre casos elucidados e não elucidados, as variáveis independentes foram as características das vítimas (sexo, idade, cor da pele), os atributos do delito (motivo apontado para a morte, horário e local do delito e uso de arma de fogo) e os procedimentos policiais mobilizados para a elucidação (testemunhas do fato, testemunhas de caráter, perícia e prisão em flagrante) ${ }^{24}$.

Em termos analíticos, inicialmente, realizamos cruzamentos bivariados, para verificar em que medida cada uma das variáveis independentes está associada às variáveis dependentes. Interpretamos os resultados com referência ao teste do qui-quadrado ${ }^{25}$. Em seguida, empregamos a regressão logística binomial, indicada quando a variável resposta

\footnotetext{
23 Uma limitação do recorte longitudinal retrospectivo é o fato de ele contabilizar crimes que ocorreram em momentos diferenciados (no caso, homicídios dolosos ocorridos entre 1964 e 2012). Os casos constantes na base de dados têm em comum o ano de encerramento (entre 2003 e 2013), mas a morte ou a tentativa se deu em diversos momentos do tempo.

${ }^{24}$ Nesse ponto, utilizamos a definição de elucidação estabelecida pelo Instituto Sou da Paz (2017), mas estamos cientes de que ela pode não abarcar a complexidade da base de dados analisada. Isso porque, em algumas situações, os pedidos de arquivamento do inquérito policial são justificados pela morte do principal suspeito (o que aconteceu em $18 \%$ dos casos analisados), o que tende a ser bastante frequente em casos nos quais a polícia categorizou a morte da vítima como decorrente de disputas do tráfico de drogas. Se na literatura internacional esses casos são considerados como elucidados, aqui optamos por deixá-los como não elucidados, para seguir a metodologia consolidada em outros estudos (Instituto Sou da Paz, 2017, 2019), que destaca que tão somente a denúncia pode indicar o fim com sucesso da fase policial.

25 Lembrando que associação não é causalidade.
} 
está categorizada em 0 (o caso foi encerrado como inquérito policial e, por isso, não tem denúncia) e 1 (o caso foi encerrado como processo penal e, por isso, tem denúncia). Dessa maneira, procuramos entender quais são os efeitos que as características da vítima, as circunstâncias do crime e os procedimentos mobilizados na investigação policial têm nas chances de elucidação.

\section{Quais são as diferenças existentes entre inquéritos policiais e processos penais?}

A teoria da vítima desvalorizada pressupõe que o assassinato de alguém de menor status social não implicará investigação policial (Black, 1976), já que essa é uma vida que não merece qualquer tipo de resposta por parte do Estado (Pastia, Davies e Wu, 2017). Em um contexto como o belo-horizontino, no qual a maioria das vítimas de homicídio doloso é composta de homens, jovens, pretos e pardos, características essas que compõem o status social inferior a que Black (1976) se refere, é razoável inferir que as taxas de elucidação são baixas porque essas são as vidas que não importam.

Os dados indicam que a teoria da vítima desvalorizada (Black, 1976) não se aplica aos casos arquivados entre 2003 e 2013 em Belo Horizonte. A maioria das mortes, tanto dos inquéritos policiais como dos processos penais, é de indivíduos do sexo masculino, sendo que inexistem diferenças estatisticamente significativas entre os dois grupos. No quesito idade na data da morte, há mais vítimas adultas nos processos penais do que nos inquéritos policiais. Por fim, a vitimização de negros ocorre mais nos processos penais do que nos inquéritos policiais, sendo essa diferença estatisticamente significativa. 
Tabela 4

Cruzamento entre as características das vítimas e a natureza do procedimento se inquérito policial (caso não elucidado) ou processo penal (caso elucidado) Belo Horizonte (2003-2013)

\begin{tabular}{|c|c|c|c|c|}
\hline \multirow{2}{*}{ Características das vítimas } & \multicolumn{2}{|c|}{ Inquéritos policiais } & \multicolumn{2}{|c|}{ Processos penais } \\
\hline & $\mathbf{N}$ & $\%$ & $\mathbf{N}$ & \\
\hline \multicolumn{5}{|l|}{ Sexo } \\
\hline Masculino & 321 & 91 & 229 & 88 \\
\hline Feminino & 31 & 9 & 32 & 12 \\
\hline Total & 352 & 100 & 261 & 100 \\
\hline \multicolumn{5}{|c|}{ Qui-quadrado: $1,099(p>0,050)$} \\
\hline \multicolumn{5}{|l|}{ Idade na data do crime } \\
\hline Jovem (até 35 anos) & 266 & 76 & 143 & 55 \\
\hline Não jovem (a partir de 36 anos) & 24 & 7 & 78 & 30 \\
\hline Sem informação & 62 & 17 & 40 & 15 \\
\hline Total & 352 & 100 & 261 & 10 \\
\hline \multicolumn{5}{|c|}{ Qui-quadrado: $57,491(\mathrm{p}<0,001)$} \\
\hline \multicolumn{5}{|l|}{ Cor da pele } \\
\hline Brancos & 89 & 25 & 45 & 17 \\
\hline Negros (pretos e pardos) & 240 & 68 & 195 & 75 \\
\hline Sem informação & 23 & 7 & 21 & 8 \\
\hline Total & 352 & 100 & 261 & 100 \\
\hline \multicolumn{5}{|c|}{ Qui-quadrado: $5,312(p<0,050)$} \\
\hline
\end{tabular}

Fonte: Elaborada pelas autoras com base em dados da pesquisa.

De acordo com a literatura internacional, é esperado que mortes ocorridas em espaços públicos, nos quais o anonimato é garantido (Jarvis, Mancik e Regoeczi, 2017); na calada da noite, quando não existem muitos indivíduos despertos como testemunhas (Liem et al., 2018); com o uso de arma de fogo, que não deixam vestígios (Pastia, Davies e Wu, 2017); e mortes que a polícia associa desde o registro inicial a "guerras de gangue" ou ao "tráfico de drogas" impliquem silêncio nos contextos sociais em que o corpo foi encontrado (Braga, Turchan e Barao, 2019) e, por isso, permaneçam impunes no sistema de justiça criminal (Carter e Carter, 2016).

Nos inquéritos policiais não elucidados, há prevalência de homicídios que ocorreram no espaço público, com uso de arma de fogo e que estavam, na visão dos policiais, associados ao tráfico de drogas. As diferenças encontradas na comparação dessas variáveis com o desfecho (se inquérito policial ou processo penal) são estatisticamente significativas (Tabela 5).

Entre os atributos do crime, chama a atenção o fato de que a associação da morte com o tráfico está presente sobremaneira nos casos encerrados como inquéritos policiais. Somente um quarto dos processos penais fazia menção a esse criminal milieu como causa do homicídio doloso, confirmando a percepção de que esses delitos são de difícil esclarecimento (Machado e Porto, 2016) ou a percepção de que tal classificação pode ser um sinal de que essa morte não tem elementos que permitam a sua elucidação (Pastia, Davies e Wu, 2017). 
Tabela 5

Cruzamento entre os atributos do crime e a natureza do procedimento - se inquérito policial (casos não elucidados) ou processo penal (casos elucidados) Belo Horizonte (2003-2013)

\begin{tabular}{|c|c|c|c|c|}
\hline \multirow{2}{*}{ Atributos do crime } & \multicolumn{2}{|c|}{ Inquéritos policiais } & \multicolumn{2}{|c|}{ Processos penais } \\
\hline & $\mathbf{N}$ & $\%$ & $\mathbf{N}$ & $\%$ \\
\hline \multicolumn{5}{|c|}{ Menção ao tráfico de drogas como causa? } \\
\hline Não & 93 & 26 & 200 & 77 \\
\hline Sim & 259 & 74 & 61 & 23 \\
\hline Total & 352 & 100 & 261 & 100 \\
\hline \multicolumn{5}{|c|}{ Qui-quadrado: $151,415(\mathrm{p}<0,001)$} \\
\hline \multicolumn{5}{|l|}{ Morte causada por arma de fogo? } \\
\hline Não & 77 & 22 & 114 & 44 \\
\hline Sim & 275 & 78 & 147 & 56 \\
\hline Total & 352 & 100 & 261 & 100 \\
\hline \multicolumn{5}{|c|}{ Qui-quadrado: $51,349(\mathrm{p}<0,001)$} \\
\hline \multicolumn{5}{|l|}{ O crime ocorreu de madrugada? } \\
\hline Não (entre 6 h00 e 23h59) & 111 & 32 & 66 & 25 \\
\hline Sim (entre 0h00 e 05h59) & 240 & 68 & 195 & 75 \\
\hline Total & 352 & 100 & 261 & 100,00 \\
\hline \multicolumn{5}{|c|}{ Qui-quadrado: 5,312 ( $p<0,050)$} \\
\hline \multicolumn{5}{|l|}{ Crime cometido no espaço público? } \\
\hline Não & 128 & 37 & 156 & 59 \\
\hline Sim & 223 & 63 & 105 & 40 \\
\hline Total & 352 & 100 & 261 & 100 \\
\hline \multicolumn{5}{|c|}{ Qui-quadrado: $38,464(p<0,001)$} \\
\hline
\end{tabular}

Fonte: Elaborada pelas autoras com base em dados da pesquisa.

Em termos de características das investigações policiais, o Brasil estaria em situação de desvantagem em comparação a outras nações em virtude dos resquícios inquisitoriais que orientam a descoberta da verdade nessa etapa (Kant de Lima, 2004). Tais características fazem com que a polícia se centre num suspeito (que precisa provar a sua inocência) em detrimento do delito apresentado (Paixão, 1982; Mingardi, 1992; Costa e Oliveira Júnior, 2016). As análises existentes indicam que o trabalho dos policiais civis consiste na busca de crimes para criminosos e não o contrário (Kant de Lima e Mouzinho, 2017), razão pela qual, se não há um suspeito em potencial, dificilmente o delito será elucidado (Paixão, 1982).

Nesse contexto, seriam priorizados os assassinatos cujo agressor foi preso em flagrante, o que dispensaria maiores investigações sobre como o crime ocorreu (Costa e Oliveira Júnior, 2016), dado que o policial já apresenta o "culpado" nas primeiras horas do inquérito (Misse, 2011). Na ausência da prisão em flagrante, as testemunhas do fato seriam determinantes no sucesso da investigação, posto que dariam detalhes impossíveis de serem extraídos das perícias (Costa, 2015). O pior cenário é aquele no qual os policiais não fazem a mínima ideia do que aconteceu e precisam recorrer ao trabalho da perícia e às testemunhas de caráter (Platero e Vargas, 2017). Esses procedimentos contribuem "pouco para a elucidação da autoria em casos típicos de mortes classificadas como homicídios" (Platero e Vargas, 2017, p. 621). 
Os dados coletados em Belo Horizonte apontam para a pertinência de algumas dessas observações. Existem diferenças estatisticamente significativas em todos os cruzamentos, reforçando a tese de que os casos não elucidados são distintos dos esclarecidos nessas dimensões (Tabela 6). É importante destacar a maior presença de perícias entre os casos não elucidados, reforçando que, quando não há qualquer sujeito para dizer o que aconteceu, os policiais precisam se valer dos elementos disponíveis no corpo sem vida para traçar uma linha de investigação (Platero e Vargas, 2017).

\section{Tabela 6}

Cruzamento entre os procedimentos mobilizados na investigação policial e a natureza do procedimento - se inquérito policial (casos não elucidados) ou processo penal (casos elucidados) - Belo Horizonte (2003-2013)

\begin{tabular}{|c|c|c|c|c|}
\hline \multirow{2}{*}{$\begin{array}{l}\text { Procedimentos mobilizados na } \\
\text { investigação policial }\end{array}$} & \multicolumn{2}{|c|}{ Inquéritos policiais } & \multicolumn{2}{|c|}{ Processos penais } \\
\hline & $\mathbf{N}$ & $\%$ & $\mathbf{N}$ & $\%$ \\
\hline \multicolumn{5}{|l|}{ Há testemunhas do fato? } \\
\hline Não & 157 & $45 \%$ & 29 & $11 \%$ \\
\hline Sim & 195 & $55 \%$ & 232 & $89 \%$ \\
\hline Total & 352 & $100 \%$ & 261 & $100 \%$ \\
\hline \multicolumn{5}{|c|}{ Qui-quadrado: $79,536(p<0,001)$} \\
\hline \multicolumn{5}{|l|}{ Há testemunhas de caráter? } \\
\hline Não & 45 & $13 \%$ & 51 & $20 \%$ \\
\hline Sim & 307 & $87 \%$ & 210 & $81 \%$ \\
\hline Total & 352 & $100 \%$ & 261 & $100 \%$ \\
\hline \multicolumn{5}{|c|}{ Qui-quadrado: $5,179(\mathrm{p}<0,050)$} \\
\hline \multicolumn{5}{|l|}{ Há perícias? } \\
\hline Não & 9 & $3 \%$ & 37 & $14 \%$ \\
\hline Sim & 343 & $97 \%$ & 224 & $86 \%$ \\
\hline Total & 352 & $100 \%$ & 261 & $100 \%$ \\
\hline \multicolumn{5}{|c|}{ Qui-quadrado: $29,152(\mathrm{p}<0,001)$} \\
\hline \multicolumn{5}{|l|}{ Há flagrante? } \\
\hline Não & 345 & $98 \%$ & 215 & $82 \%$ \\
\hline Sim & 7 & $2 \%$ & 46 & $18 \%$ \\
\hline Total & 352 & $100 \%$ & 261 & $100 \%$ \\
\hline \multicolumn{5}{|c|}{ Qui-quadrado: $46,390(\mathrm{p}<0,001)$} \\
\hline
\end{tabular}

Fonte: Elaborada pelas autoras com base em dados da pesquisa.

Uma última dimensão que merece destaque é o tempo da investigação, que afeta diretamente a chance de elucidação. Carter e Carter (2016) asseguram que delitos que não foram elucidados nas horas subsequentes dificilmente serão resolvidos pela polícia nos meses e anos que seguem à abertura da investigação. Inclusive, há elevada concordância na literatura internacional de que, quanto mais o caso demora para ser investigado, maior é a probabilidade de este permanecer sem solução (Pastia, Davies e Wu, 2017, p. 13).

Em Belo Horizonte, verificamos que os casos encerrados como inquéritos policiais demoram, em média, 2.356 dias (ou 6,45 anos) para serem finalizados. Já os casos transformados em processo penal são encerrados na Polícia Civil, em média, com 524 dias $(1,4$ ano). A diferença em termos de duração da fase policial se torna evidente no Boxplot 
$1^{26}$. Enquanto os casos que foram convertidos em processos penais dificilmente têm investigação policial com duração superior a cinco anos, a barra que sinaliza a mediana de tempo dos casos encerrados como inquéritos policiais está acima desse limite ${ }^{27}$. Como somente $8,1 \%$ dos casos foram esclarecidos após cinco anos, consideramos este como o limite temporal para que a investigação policial se converta em processo penal.
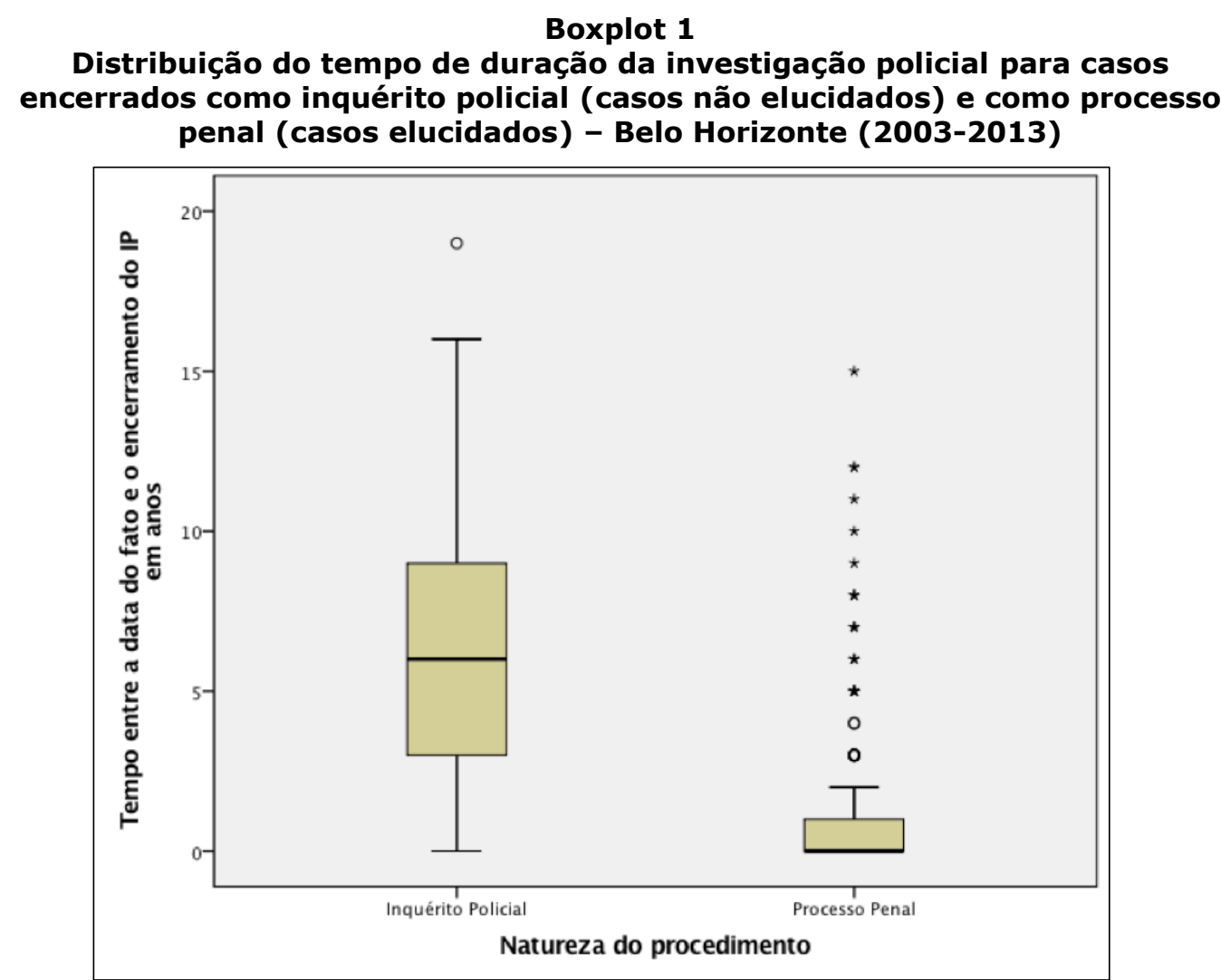

Fonte: Elaborado pelas autoras com base em dados da pesquisa.

De acordo com os dados apresentados nesta seção, existem diferenças estatisticamente significativas entre casos não elucidados (encerrados como inquéritos policiais) e elucidados (encerrados como processos penais) no que diz respeito às

${ }^{26}$ O Boxplot é um gráfico que resume as estatísticas descritivas principais de um fenômeno. Seu limite inferior é o valor mínimo da distribuição, enquanto o último asterisco representa o maior valor em termos de tempo entre a data do fato e a do encerramento da investigação policial. A vantagem desse gráfico é o desenho de uma caixa que engloba do primeiro ao terceiro quartil, além de uma linha no meio, indicando a posição da mediana.

27 Ao contrário da hipótese do parecerista anônimo, não há uma correlação perfeita entre o tempo de cinco anos e a elucidação do homicídio. A correlação de Pearson nesse caso foi de 0,4 , sendo que $8,1 \%$ dos casos analisados foram esclarecidos após cinco anos e $22 \%$ foram encerrados - sem elucidação - antes mesmo dos cinco anos. Outros testes estatísticos foram realizados para que o tempo de cinco anos pudesse ser inserido no modelo de regressão logística sem apresentar colinearidade com as demais variáveis. 
características da vítima (com exceção do sexo), aos atributos do crime, aos procedimentos policiais mobilizados na investigação e ao tempo de duração da fase policial.

\section{Determinantes da elucidação: a literatura internacional explica a dinâmica de Belo Horizonte?}

Nesta seção, nos interessa verificar quais são as variáveis que explicam a diferença existente entre inquérito policial e processo penal. Com isso, queremos entender se os determinantes da elucidação em Belo Horizonte são os mesmos apontados na literatura internacional sobre o tema.

Os resultados dispostos na Tabela 7 indicam que a teoria da vítima desvalorizada de Black (1976) se aplica apenas em parte à realidade nacional. Ao contrário do verificado nas pesquisas estrangeiras, o sexo não tem relevância estatística. No caso da cor da pele, é preciso uma pequena digressão para que o resultado apresentado pelo modelo de regressão logística binomial seja adequadamente compreendido.

Tabela 7

Resultados do modelo de regressão logística binomial estimando as chances do caso de homicídio doloso consumado ser encerrado como processo penal em detrimento de inquérito policial - Belo Horizonte (2003-2013)

\begin{tabular}{|c|c|c|c|c|c|c|c|}
\hline Tipo de variáveis & Variáveis inseridas no modelo & B & E.P. & Wald & gl & Sig. & $\operatorname{Exp}(B)$ \\
\hline \multirow{6}{*}{ Características da vítima } & Homem & 0,086 & 0,476 & 0,032 & 1 & 0,857 & 1,089 \\
\hline & Referência: mulher & & & & & & \\
\hline & Negro (pretos e pardos) & 0,737 & 0,351 & 4,407 & 1 & 0,056 & 2,090 \\
\hline & Referência: branco & & & & & & \\
\hline & Jovem (até 35 anos) & $-2,504$ & 0,472 & 28,203 & 1 & 0,000 & 0,082 \\
\hline & Referência: Não jovem (a partir de 36 anos) & & & & & & \\
\hline \multirow{8}{*}{ Atributos do crime } & Menção ao tráfico de drogas como causa da morte & $-1,79$ & 0,296 & 36,652 & 1 & 0,000 & 0,167 \\
\hline & Referência: sem menção ao tráfico & & & & & & \\
\hline & Local Público & $-0,486$ & 0,297 & 2,673 & 1 & 0,102 & 0,615 \\
\hline & Referência: local privado & & & & & & \\
\hline & Arma de Fogo & $-0,912$ & 0,343 & 7,072 & 1 & 0,008 & 0,402 \\
\hline & Referência: arma branca & & & & & & \\
\hline & O crime ocorreu de madrugada (entre 0h e 5h59) & $-1,412$ & 0,369 & 14,661 & 1 & 0,000 & 0,244 \\
\hline & $\begin{array}{l}\text { Referência: o crime não ocorreu de madrugada (entre } \\
6 \text { h e 23h59) }\end{array}$ & & & & & & \\
\hline \multirow{8}{*}{ Procedimentos policiais } & Testemunhas Fato & 1,786 & 0,379 & 22,207 & 1 & 0,000 & 5,965 \\
\hline & Referência: sem testemunhas do fato & & & & & & \\
\hline & Testemunhas Caráter & $-0,188$ & 0,388 & 0,235 & 1 & 0,628 & 0,829 \\
\hline & Referência: sem testemunhas de caráter & & & & & & \\
\hline & Perícias & $-0,88$ & 0,595 & 2,189 & 1 & 0,139 & 0,415 \\
\hline & Referência: sem perícias & & & & & & \\
\hline & Prisão em flagrante & 1,312 & 0,541 & 5,884 & 1 & 0,015 & 3,712 \\
\hline & Referência: IP sem flagrante & & & & & & \\
\hline \multirow{3}{*}{ Tempo de duração } & Investigação policial com duração de até cinco anos & 2,793 & 0,42 & 44,232 & 1 & 0,000 & 16,326 \\
\hline & $\begin{array}{l}\text { Referência: Investigação policial com duração maior } \\
\text { que cinco anos }\end{array}$ & & & & & & \\
\hline & Constante & 0,663 & 0,992 & 0,448 & 1 & 0,504 & 1,941 \\
\hline
\end{tabular}

Fonte: Elaborada pelas autoras com base em dados da pesquisa R quadrado Cox e Snell: 0,546. Número de casos: 511 . 
Ao contrário das metodologias empregadas pelo Instituto Brasileiro de Geografia e Estatística para a classificação racial, as quais primam pela autoclassificação do entrevistado em termos de cor da pele (Muniz, 2012), no sistema de justiça criminal a forma de categorização da raça é distinta. Nos casos de homicídio, a autoclassificação seria inviável porque a vítima não está mais viva, fazendo com que a cor da cútis (termo constante no registro de ocorrência) seja dada pelo policial, que irá provavelmente codificar aquele sujeito como negro ou branco de acordo com as suas percepções (Costa Ribeiro, 1995).

Essa ressalva é importante porque a variável cor da pele, codificada em brancos e negros, não apresentou significância estatística, já que a maioria dos casos analisados era de vítimas pretas ou pardas, assim classificadas de acordo com a percepção do policial. Porém, o uso de outras metodologias classificatórias (como a família dizer a cor da pele do morto) pode levar a resultados distintos do obtido neste artigo.

A idade foi a única variável, entre as características do morto, que apresentou significância estatística. Os jovens são as vítimas desvalorizadas (Black, 1976) em Belo Horizonte. Assassinatos de pessoas com até 35 anos de idade na data do óbito têm baixas chances de elucidação. Ser classificado nessa faixa etária diminui em $92 \%$ as chances de início do processo penal, o que seria uma amostra muito evidente de que o genocídio da juventude no Brasil não encontra nos meios judiciais qualquer tipo de responsabilização (Sinhoretto et al., 2014).

Quanto aos atributos do crime, somente o local em que o delito foi perpetrado não apresentou significância estatística. Se, desde o momento do registro policial, a morte violenta está associada ao tráfico de drogas, o caso tem $83 \%$ menos chance de se converter em processo penal (quando comparado a crimes cujos inquéritos policiais não contam com essa menção). Nessa dimensão específica, é bom destacar que estamos diante de uma classificação feita pela polícia com base em suas representações e lógicas em uso sobre os atributos diferenciados que a morte causada pelo tráfico de drogas tem (Machado e Porto, 2016; Platero e Vargas, 2017).

Resultados semelhantes foram encontrados em pesquisas realizadas nos Estados Unidos da América, país no qual os homicídios têm menos chance de serem elucidados quando são relacionados ao tráfico de drogas ou a gangues (Petersen, 2017). Uma análise recente constatou que, "controlando por outros fatores, os homicídios de gangues e drogas em Boston foram quase $69 \%$ menos propensos ao esclarecimento quando comparados a homicídios classificados como não-gangues e não-drogas" (Braga, Turchan e Barao, 2019, p. 360).

Os estudos sobre processos de classificação de crimes pela polícia e pela justiça têm informado que essa associação da causa do crime, feita pelos policiais nas primeiras horas de investigação, dificilmente é revertida na justiça pela promotoria ou pelo juiz, especialmente nos processos penais de homicídios (Ribeiro e Couto, 2017) ou tráfico de 
drogas (Jesus, 2016). Logo, a classificação dos policiais tem implicações em termos de percepções dos operadores, o que irá reverberar nos processos decisórios subsequentes. Por essa razão, tal categorização pode transformar o registro numa espécie de crime que não merece responsabilização (na direção da teoria da vítima desvalorizada de Black, 1976).

Em Belo Horizonte, assassinatos cometidos com o uso da arma de fogo têm $60 \%$ menos chances de superar a fase policial. A literatura internacional sugere que tais mortes são mais difíceis de elucidar por não contarem com evidências deixadas por lutas, agressões ou outras situações de contato físico, que podem ser verificadas nos exames do corpo de delito, aumentando a chance de elucidação (Liem et al., 2018; Regoeczi, Jarvis e Mancik, 2020).

Os homicídios que ocorreram de madrugada (entre 0h e 5h59) têm 76\% menos chances de elucidação em comparação àqueles que foram perpetrados durante o dia. De acordo com os estudos internacionais, essa variável está muito correlacionada com a presença de testemunhas (Jarvis, Mancik e Regoeczi, 2017), já que mortes resultantes de acertos de contas tendem a ocorrer nesse período, quando não há qualquer indivíduo presente para atestar quem foi o autor do fato.

No que se refere à associação entre práticas de investigação e chance de elucidação, os resultados encontrados a partir do modelo de regressão logística estão em acordo com a literatura internacional (Braga e Dusseault, 2018) e nacional (Costa e Oliveira Júnior, 2016). Duas foram as variáveis que não apresentaram significância estatística: testemunhas de caráter e presença de perícia.

As testemunhas de caráter são as que vão à polícia dizer sobre o caráter dos envolvidos no crime e ajudam a reunir informações sobre quem era a vítima ou o provável autor, mas em nada contribuem para o desfecho do caso (Misse, 2011). As perícias não têm destaque porque, na tradição inquisitorial, "a utilização das tecnologias de DNA ao serviço da justiça é, em parte ou significativamente, subordinada ao estabelecimento de narrativas criminais e aos elementos de prova que se pretende consolidar" (Santos, 2018, p. 41). Se não há prisão em flagrante ou testemunha ocular do delito, não há um suspeito a quem a morte possa ser imputada, que é a lógica em curso dos policiais civis (Kant de Lima e Mouzinho, 2017). Nesse caso, os investigadores não sabem como caminhar na condução do inquérito policial, o que dificulta a conversão em processo penal (Platero e Vargas, 2017).

Entre as variáveis relacionadas aos procedimentos policiais que apresentaram significância estatística, a que teve maior efeito foi a testemunha do fato, que aumenta em quase $500 \%$ a chance de o caso ser convertido em processo penal em comparação aos casos que não contam com esse elemento. Esse resultado reforça a perspectiva de que a investigação policial no Brasil é excessivamente centrada em testemunhos, relegando a segundo plano provas periciais, que poderiam contradizer essas narrativas (Kant de Lima, 2004; Platero e Vargas, 2017). 
A segunda variável com significância estatística foi a prisão em flagrante, que aumenta em $271 \%$ as chances de a investigação policial resultar em processo penal em comparação às situações em que não foi possível prender o assassino nas horas subsequentes ao crime. A prisão do suspeito nas primeiras horas faz com que o inquérito policial seja considerado bem-sucedido, dispensando a coleta de outros elementos para subsidiar a denúncia do promotor de justiça (Costa, 2015).

Por fim, inserimos a variável binária de tempo de duração do inquérito policial. Investigações que duraram menos de cinco anos têm $1.532 \%$ mais chances de se transformar em processos penais do que aquelas que duraram mais de cinco anos. Essa é a variável com maior razão de chance, o que confirma a constatação de outros estudos de que, quanto maior o tempo, maior a certeza de que a investigação policial não resultará em processo penal (Vargas, 2014; Costa, 2015; Azevedo e Sinhoretto, 2018; Carter e Carter, 2016; Pastia, Davies e Wu, 2017; Regoeczi, Jarvis e Riedel, 2008.

Quando analisamos as razões de chance $(\operatorname{Exp}(B))$ das variáveis que apresentaram significância estatística no modelo de regressão logística binomial, verificamos que as características dos homicídios dolosos (ligação com o tráfico, ocorrência durante a madrugada e com uso de arma de fogo) diminuem as chances de elucidação enquanto os procedimentos de investigação aumentam as chances de transformação em processo penal. Diante dessas conclusões, é possível afirmar que a capacidade da polícia para responder rapidamente aos chamados informando a ocorrência de violências letais e intencionais pode contribuir para ocorrência de prisões e encontro de testemunhas, aumentando as chances de elucidação (Braga, Turchan e Barao, 2019). Por outro lado, vítimas jovens tendem a ser casos categorizados pelos policiais como decorrentes do tráfico de drogas, os quais usualmente ocorrem de madrugada através do uso de arma de fogo e que, por isso, não contam com testemunhas que possam colaborar com a investigação, dada a baixa legitimidade da polícia nessas áreas (Misse, 2011), o que faz com que essas mortes tenham menores chances de elucidação.

\section{Considerações finais}

O assassinato da vereadora Marielle Franco em 14 de março de 2018 é um delito que ainda carece de maiores explicações. Cometido à noite, em via pública, por meio de disparo de arma de fogo, sem a presença de testemunhas ou prisão em flagrante do responsável por essa violência, esse homicídio é um exemplo das mortes que permanecem impunes no Brasil. A divulgação pela mídia e a atenção que tal crime recebeu não foram suficientes para minimizar o peso dos elementos que caracterizam tal delito em sua precária elucidação.

Partindo desse exemplo dramático da ineficiência do sistema de justiça criminal em responder adequadamente sobre as mortes que chegam a seu conhecimento, a 
proposta deste artigo foi identificar quais são os elementos que contribuem para a elucidação dos homicídios dolosos em Belo Horizonte.

Como ainda não contamos com uma base de dados que reúna as informações da polícia e da justiça, a opção encontrada foi recorrer ao desenho longitudinal retrospectivo para contrastar casos encerrados como inquéritos policiais com aqueles arquivados como processos penais. Aplicando essa metodologia à documentação disponível no Tribunal do Júri em Belo Horizonte, foi possível construir uma base de dados com informações relativas a casos encerrados entre os anos de 2003 e 2013.

Para identificar quais variáveis deveriam ser utilizadas para estimar as chances de esclarecimento, a literatura internacional foi revisada. Em razão dos inúmeros trabalhos existentes sobre elucidação de mortes intencionais, apenas os publicados nos últimos anos, que traziam um balanço da produção desse campo, foram utilizados como ponto de partida. Tais pesquisas organizam os determinantes do esclarecimento em características da vítima, atributos do crime e procedimentos mobilizados na investigação policial. Como o tempo é um elemento definidor do sucesso da investigação policial, posto que a demora aumenta o risco de o caso não se converter em processo penal, inserimos uma variável de diferenciação do tempo do inquérito policial, dividindo os casos entre aqueles que se encerraram em até cinco anos e aqueles que ultrapassaram esse marco.

Em seguida, a partir de modelos de regressão logística binomial, procuramos identificar quais são as variáveis que melhor explicam a chance de elucidação controlando pelo tempo de duração da investigação policial. Constatamos que os casos esclarecidos são muito semelhantes aos que foram transformados em processos penais no que se refere às características das vítimas, majoritariamente homens, e também no que diz respeito à cor da pele, já que a maioria dos casos com informação é classificada como não branco. 0 destaque fica por conta de a vítima ter até 35 anos (na data do crime), que foi um fator de diferenciação entre inquéritos policiais e processos penais no modelo de regressão, indicando que os homicídios de jovens são os que possuem maiores chances de permanecer impunes em Belo Horizonte.

Quanto aos atributos do incidente, verificamos que os casos com menções ao tráfico de drogas como causa da morte, que aconteceram de madrugada e com uso de arma de fogo são os que têm menores chances de elucidação. Essas são as violências para as quais a polícia não consegue apontar um suspeito que possa ser denunciado, o que contribui para que elas sejam represadas na fase policial. Num país em que a maioria dos homicídios tem exatamente essas características, é possível entender por que as taxas de elucidação dificilmente superam a marca dos 20\% (UNODC, 2019).

Em termos de elementos investigativos, os casos elucidados são distintos quanto à presença de testemunhas de fato e prisão em flagrante, o que confirma os resultados de pesquisas nacionais (Costa e Oliveira Júnior, 2016) e internacionais (Carter e Carter, 2016; Braga e Dusseault, 2018) sobre essa temática. 
Os resultados do modelo de regressão reforçam o entendimento de que apenas casos com um conjunto probatório mínimo têm chances de superar o maior gargalo de todos, qual seja, a fase de investigação policial. Se a ação do policial ocorre logo após o delito, ele tem chances de identificar testemunhas e prender o responsável imediatamente, fazendo com que o perpetrador da morte possa ser responsabilizado por meio do processo penal.

Na América Latina, Bergman (2018) argumenta que somente os casos com prisão em flagrante têm chance de sobreviver a todas as etapas do fluxo de procedimento e ser encerrados com condenação. Assim, estreitar as relações entre polícia e comunidade para que todos os homicídios sejam prontamente registrados e investigados parece ser um enorme desafio rumo a um menor represamento de casos na fase policial. Apenas dessa maneira será possível à polícia chegar ao local do delito quando o assassino ainda está com a mão na arma, o que aumenta não apenas as chances de esclarecimento (Costa, 2015), como também a velocidade de processamento (Vargas, 2004) e as chances de condenação (Costa e Oliveira Júnior, 2016). Se vamos ser capazes de promover tamanha revolução em nossas polícias civis, só o futuro dirá.

\section{Referências bibliográficas}

AzeVedo, R.; Sinhoretto, J. "O sistema de justiça criminal na perspectiva da antropologia e da sociologia". BIB, São Paulo, no 84, p. 188-215, abr. 2018.

BANZIGER, M.; KILliAS, M. "Unsolved homicides in Switzerland: patterns and explanations". European Journal of Criminology, vol. 11, no 5, p. 619-634, 2014.

Bergman, M. More money, more crime: prosperity and rising crime in Latin America. Oxford: University Press, 2018.

BLACK, D. The behavior of law. New York: Emerald Group Publishing, 1976.

. The manners and customs of the police. New York: Academic Press, 1980.

Braga, A. A.; Dusseault, D. "Can homicide detectives improve homicide clearance rates?". Crime and Delinquency, vol. 64, no 3, p. 283-315, 2018.

BRAgA, A. A.; TURChAN, B.; BARAO, L. "The influence of investigative resources on homicide clearances". Journal of Quantitative Criminology, vol. 35, no 2, p. 337-364, 2019.

CANo, I.; DuARTE, T. "A mensuração da impunidade no sistema de justiça criminal do Rio de Janeiro". Pesquisas Aplicadas em Segurança Pública, Brasília, ano II, no 4, Senasp, 2010.

CARTER, D. L.; CARTER, J. G. "Effective police homicide investigations: evidence from seven cities with high clearance rates". Homicide Studies, vol. 20, no 2, p. 150-176, 2016.

Costa Ribeiro, C. A. Cor e criminalidade: estudo e análise da justiça no Rio de Janeiro (1900-1930). Rio de Janeiro: Editora UFRJ, 1995.

Costa, A. T. M. "O inquérito policial no Distrito Federal". Cadernos Temáticos da Conseg, vol. 6, p. 53-64, 2009. 
SERÁ QUE VAI VIRAR PROCESSO? DETERMINANTES DA ELUCIDAÇÃO DOS HOMICÍDIOS DOLOSOS EM UMA CIDADE BRASILEIRA

Costa, A. T. M. "A (in)efetividade da justiça criminal brasileira: uma análise do fluxo de justiça dos homicídios no Distrito Federal". Civitas - Revista de Ciências Sociais, vol. 15, no 1, p. 11-26, 2015.

Costa, A. T. M.; LIMA, R. S. "Estatísticas oficiais, violência e crime no Brasil". BIB, São Paulo, no 84, p. 81-106, 2018.

COSTA, A. T. M.; Oliveira JúNior, A. "Novos padrões de investigação policial no Brasil". Sociedade e Estado, vol. 31, no 1, p. 147-164, 2016.

COSTA, A. T. M.; ZACKESKI, C. M.; MACIEL, W. C. "Investigação e processamento dos crimes de homicídio na área metropolitana de Brasília". Revista Brasileira de Segurança Pública. São Paulo, vol. 10, p. 36-54, mar. 2016.

FERRAZ, T. S. "Articulação e comunicação entre os agentes do Estado: possíveis impactos sobre a impunidade nos crimes de homicídio". Revista da Ajuris, vol. 45, no 145, 267-292, 2019.

Hough, R. M. "The investigation of homicide". Homicide Studies, vol. 23, no 2, p. 87-92, 2019.

InSTITUTO Sou dA PAZ. Onde mora a impunidade?. São Paulo: Instituto Sou da Paz, 2017. Disponível em: <http://www.soudapaz.org/upload/pdf/index_isdp_web.pdf>. Acesso em: 3 dez. 2017.

. Onde mora a impunidade?. São Paulo: Instituto Sou da Paz, 2019. Disponível em:

<http://soudapaz.org/wp-content/uploads/2019/11/index_isdp_web.pdf>. Acesso em: 3 mar. 2020.

JARVIS, J. P.; MANCIK, A.; REgOECZI, W. C. "Police responses to violent crime: reconsidering the mobilization of law". Criminal Justice Review, vol. 42, n० 1, p. 5-25, 2017.

JeSUS, M. G. M. "'O que está no mundo não está nos autos': a construção da verdade jurídica nos processos criminais de tráfico de drogas". Tese de Doutorado. Universidade de São Paulo, 2016.

KANT DE LimA, R. "Polícia e exclusão na cultura judiciária". Tempo Social, vol. 9, no 1, p. 169-183, 1997.

. "Direitos civis e direitos humanos: uma tradição judiciária pré-republicana?". São Paulo em Perspectiva, vol. 18, no 1, p. 49-59, 2004.

KANT DE LIMA, R.; MouZINHO, G. M. P. "Produção e reprodução da tradição inquisitorial no Brasil: entre delações e confissões premiadas". Dilemas - Revista de Estudos de Conflito e Controle Social, vol. 9, no 3, p. 505-529, 2017.

KeEL, T. G.; JARVIS, J. P.; MUIRHEAD, Y. E. "An exploratory analysis of factors affecting homicide investigations: examining the dynamics of murder clearance rates". Homicide Studies, vol. 13, no 1 , p. 50-68, 2009.

LIEM, M., et al. "Homicide clearance in Western Europe". European Journal of Criminology, vol. 16, 2018.

MACHADO, B. A.; PORTO, M. S. G. "Violência e justiça criminal na área metropolitana de Brasília: dinâmicas organizacionais e representações sociais". Tempo Social, vol. 28, n० 3, p. 217-242, 2016.

MingARDI, G. Tiras, trutas e gansos. São Paulo: Página Aberta, 1992.

MISSE, M. "Crime, sujeito e sujeição criminal: aspectos de uma contribuição analítica sobre a categoria 'bandido'". Lua Nova, no 79, 2010.

. "O papel do inquérito policial no processo de incriminação no Brasil: algumas reflexões a partir de uma pesquisa". Sociedade e Estado, vol. 26, nº 1, p. 15-27, 2011. 
MisSE, M.; VARgAS, J. D. "O fluxo do processo de incriminação no Rio de Janeiro na década de 50 e no período 1997-2001: comparação e análise". In: XIII Congresso Brasileiro de Sociologia, Recife, 2007.

Muniz, J. O. "Preto no branco? Mensuração, relevância e concordância classificatória no país da incerteza racial". Dados, vol. 55, no 1, p. 251-282, 2012.

Oliveira, M. V. B. N.; MACHADO, B. A. "The flux of the justice system as a technique for empirical research in the field of public security". Revista Direito e Práxis, vol. 9, no 2, p. 781-809, 2018.

PAES, V. Crimes, procedimentos e números: estudo sociológico sobre a gestão dos crimes na França e no Brasil. Rio de Janeiro: Garamond, 2013.

PAIXÃo, A. L. "A organização policial numa área metropolitana". Dados, vol. 25, no 1, p. 63-85, 1982.

PASTIA, C.; DAVIES, G.; WU, E. "Factors influencing the probability of clearance and time to clearance of Canadian homicide cases, 1991-2011". Homicide Studies, vol. 21, no 3, p. 199-218, 2017.

Petersen, N. "Neighborhood context and unsolved murders: the social ecology of homicide investigations". Policing and Society, vol. 27, no 4, p. 372-392, 2017.

Platero, K. A. S.; Vargas, J. D. "Homicídio, suicídio, morte acidental... 'O que foi que aconteceu?"'. Dilemas - Revista de Estudos de Conflito e Controle Social, vol. 10, no 3, p. 621-641, 2017.

RATtON, J. L.; Cireno, F. "Violência endêmica: homicídios na cidade do Recife - Dinâmica e fluxo no sistema de justiça criminal". Revista do Ministério Público de Pernambuco, vol. 6, p. 17-157, 2007.

RegoeCZI, W. C.; JARVIS, J.; MANCIK, A. "Homicide investigations in context: exploring explanations for the divergent impacts of victim race, gender, elderly victims, and firearms on homicide clearances". Homicide Studies, vol. 24, no 1, p. 25-44, 2020.

Regoeczi, W. C.; JARVis, J.; Riedel, M. "Clearing murders: is it about time?". Journal of Research in Crime and Delinquency, vol. 45, no 2, p. 142-162, 2008.

Ribeiro, L. "A produção decisória do sistema de justiça criminal para o crime de homicídio: análise dos dados do estado de São Paulo entre 1991 e 1998". Dados, vol. 53, nº 1, p. 159-194, 2010.

Ribeiro, L. M. L.; Couto, V. A. "Tipos de homicídio e formas de processamento: existe relação?". Revista Semestral do Departamento e do Programa de Pós-Graduação em Sociologia da UFSCar, vol. 7, no 2, p. 417, 2017.

Ribeiro, L. M. L.; LimA, F. M.; MAIA, Y. C. "Fluxo e tempo do sistema de justiça criminal: uma análise dos casos de homicídios dolosos arquivados em Belo Horizonte (2003-2013)". Belo Horizonte:

Centro de Estudos de Criminalidade e Segurança Pública, 2017. Disponível em:

<https://www.crisp.ufmg.br/wp-content/uploads/2017/08/Fluxo-e-Tempo-Final.pdf>. Acesso em: 16 abr. 2020

RIEDEL, M. "Homicide arrest clearances: a review of the literature". Sociology Compass, vol. 2, no 4, p. $1.145-1.164,2008$.

Rifiotis, T. "Fluxo da justiça criminal em casos de homicídios dolosos na região metropolitana de Florianópolis entre os anos de 2000 e 2003". Florianópolis: UFSC, 2006. Mimeo.

Roberts, A.; LyOnS, C. J. "Hispanic victims and homicide clearance by arrest". Homicide Studies, vol. $15, n^{\circ} 1$, p. 48-73, 2011. 
SANTOS, F. "Crime, narrativa e DNA: os desafios da prova de DNA no processo inquisitorial". Lex Humana, vol. 9, no 2, p. 40-67, 2018.

SAPORI, L. F. Segurança pública no Brasil: desafios e perspectivas. Rio de Janeiro: Ed. FGV, 2007.

SCHROEDER, D. A.; WHITE, M. D. "Exploring the use of DNA evidence in homicide investigations: implications for detective work and case clearance". Police Quarterly, vol. 12, no 3, p. 319-342, 2009.

SinHORETTO, J., et al. "A filtragem racial na seleção policial de suspeitos: segurança pública e relações raciais". Segurança pública e direitos humanos: temas transversais, vol. 5. Ministério da Justiça, Brasília, p. 121-160, 2014.

SOARES, L. E. Violência e política no Rio de Janeiro. Rio de Janeiro: Relume-Dumará, 1996.

TRINDADE, R. F. C., et al. "Mapa dos homicídios por arma de fogo: perfil das vítimas e das agressões". Revista da Escola de Enfermagem da USP, vol. 49, no 5, p. 748-755, 2015.

UNODC - United Nations OfFice on DRUgS AND CRIME. Global study on homicide 2019: trends, contexts, data. Viena: UNODC, 2019.

VARGAS, J. D. "Estupro: que justiça? Fluxo do funcionamento e análise do tempo da justiça criminal para o crime de estupro". Tese de Doutorado em Sociologia, Instituto Universitário de Pesquisas do Rio de Janeiro (Iuperj), Rio de Janeiro, 2004.

. "Fluxo do sistema de justiça criminal. Crime, polícia e justiça no Brasil". Contexto, São Paulo, vol. 1, p. 412-423, 2014.

VARgAS, J. D.; RodRIGUES, J. N. L. "Controle e cerimônia: o inquérito policial em um sistema de justiça criminal frouxamente ajustado". Sociedade e Estado, vol. 26, no 1, p. 77-96, 2011.

\begin{abstract}
Will it become a trial? Determinants of clearance of intentional homicides in a Brazilian city

In this paper we analyzed data from police investigations and trials of intentional homicides shelved in Belo Horizonte between 2003 and 2013 in order to understand the clearance's determinants. As independent variables, we used the characteristics of victim, crimes' attributes and police procedures. The results inform that the homicides features and police truth-finding methods (centered on the flagrante delicto and the presence of eyewitnesses) were the variables that explained the clearance likelihood. However, the length of time may affect this result, since police inquiries that are not completed within five year are not likely to be trialed.
\end{abstract}

Keywords: clearance; homicide; Brazil; police; criminal justice system

\title{
Resumen
}

¿Se convertirá en un proceso? Determinantes del aclaramiento de homicidios en una ciudad brasileña En este artículo analizamos datos de investigaciones policiales y casos penales de homicidios intencionales, presentados en Belo Horizonte entre 2003 y 2013, para comprender los determinantes del aclaramiento de este tipo de delitos. Como variables predictores, utilizamos las características de la víctima, los atributos del delito y la naturaleza de los procedimientos policiales. Los resultados indican que las características del asesinato y los métodos para descubrir la verdad (centrados en el acto y la presencia de testigos oculares del crimen) son las variables que mejor explican la diferencia entre los casos presentados ante la policía y la justicia. Sin embargo, el curso del tiempo tiene un papel destacado, ya que las investigaciones policiales que no se han cerrado en cinco años tienen una posibilidad insignificante de convertirse en un proceso penal.

Palabras clave: aclaración; homicidios; Brasil; investigación policial; sistema de justicia penal 


\section{Résumé}

Cela deviendra-t-il un procès? Déterminants de l'élimination des homicides intentionnels dans une ville brésilienne

Dans cet article, nous avons analysé les données des enquêtes policières et des procès d'homicides intentionnels mis à l'écart à Belo Horizonte entre 2003 et 2013 afin de comprendre les déterminants de l'autorisation. En tant que variables indépendantes, nous avons utilisé les caractéristiques de la victime, les attributs des crimes et les procédures policières. Les résultats indiquent que les caractéristiques des homicides et les méthodes d'enquête policière (centrées sur le flagrant délit et la présence de témoins oculaires) étaient les variables qui expliquaient la probabilité de libération. Cependant, la durée peut affecter ce résultat, car les enquêtes policières qui ne sont pas terminé dans les cinq ans ne seront probablement pas jugées.

Mots clés: dégagement; homicide; Brésil; police; système de justice pénale

Artigo submetido à publicação em 27 de março de 2019.

Versão final aprovada em 20 de fevereiro de 2020.

Opinião Pública adota a licença Creative Commons CC-BY. 